\title{
PKM INDUSTRI KRUPUK LEMPENG DI BANTUL
}

\author{
Sri Setyowati ${ }^{1}$, Edi Iskandar ${ }^{2)}$ \\ 1) Ilmu Keperawatan STIKes Surya Global Yogyakarta \\ ${ }^{2)}$ Teknik Informatika STMIK Akakom Yogyakarta \\ e-mail: setyoku.sg@gmail.com', edi_iskandar@akakom.ac.id ${ }^{2)}$,
}

\begin{abstract}
Abstrak
Karak atau krupuk lempeng atau krupuk nasi atau juga biasa disebut gendar merupakan kerupuk yang sangat familiar dan digemari oleh sebagian besar masyarakat terutama di Yogyakarta dan di pulau Jawa. Salah satu sektor industri kecil menengah yang berada di Kabupaten Bantul adalah industi krupuk lempeng atau karak yang tersebar diseluruh wilayah Bantul, terutama di Kecamatan Sewon dan menjadi salah satu penopang perekonomian masyarakat. Sektor usaha yang menjadi mitra dalam kegiatan PKM ini adalah Industri "Kerupuk Lempeng Mbak Gendhuk" yang terletak di Dusun Kepek I Timbulharjo Sewon Bantul Yogyakarta. Permasalahan yang dapat diidentifikasi dari pengrajin kerupuk lempeng tersebut antara lain yaitu : 1) Keterbatasan modal, 2) Keterbatasan, 3) Penggunaan alat tradisional dan manual terutama alat pemotong krupuk, 4) Produksi masih memakai bahan tambahan boraks atau bleng, 5) Hasil produksi dikemas seadanya dan belum ada ijin PIRT, 6) Kurangnya pengetahuan pemilik dan tenaga kerja terhadap teknologi informasi sehingga sarana pemasaran terbatas. Untuk meningkatkan nilai ekonomi dari industi krupuk lempeng terutama dalam hal penggunakaan alat tekhnologi tepat guna dan penggunaan bahan tambahan makanan yang sehat diperlukan pendampingan. Dalam PKM ini akan dilakukan beberapa kegiatan yaitu : 1) Penerapan teknologi tepat guna, 2) Pelatihan pembuatan krupuk lempeng dengan bahan tambahan pangan STTP (Sodium tripolifosfat) sebagai pengganti boraks, 3) Pengemasan produk dan IRT dan 4) Penerapan teknologi informasi terutama dalam memperluas jangkauan pemasaran.
\end{abstract}

Kata Kunci : UKM, Industri, STTP, Krupuk Lempeng, Bantul

\section{PENDAHULUAN}

\section{a. Analisis Kebutuhan}

Angkatan kerja di Kabupaten Bantul pada tahun 2013 sebesar 519.558 dengan jumlah pengangguran 26.188 atau $5,01 \%$. Di sektor ekonomi yang menyerap tenaga kerja paling besar adalah sektor pertanian kemudian disusul sektor jasa-jasa lainnya. Sektor yang potensial dikembangkan yaitu sektor pariwisata, sektor perdagangan dan industri terutama industri kecil menengah serta kerajinan. Pengangguran di Bantul menjadi problematika sosial yang cukup serius karena karakter pengangguran Bantul menyangkut sebagian tenaga-tenaga profesional dengan tingkat pendidikan tinggi [1].

Salah satu sektor industri kecil menengah yang berada di Kabupaten Bantul adalah industi krupuk lempeng atau karak yang tersebar diseluruh wilayah Bantul, terutama di Kecamatan Sewon dan menjadi salah satu penopang perekonomian masyarakat.

Karak atau krupuk lempeng atau krupuk nasi atau juga biasa disebut gendar merupakan kerupuk yang sangat familiar dan digemari oleh sebagian besar masyarakat terutama di Yogyakarta dan di pulau jawa. Karak merupakan produk kering dari proses penggorengan berbentuk lempengan tipis, umumnya berbentuk persegi panjang, yang terbuat dari bahan dasar beras dengan cita rasa asin dan gurih sesuai dengan bumbu-bumbu yang ditambahkan.

Dewasa ini sekitar 55 persen bahan pangan yang dikonsumsi masyarakat merupakan bahan olahan. Dalam usaha mempertahankan mutu dan nilai gizi bahan olahan, masyarakat banyak melibatkan penggunaan bahan tambahan pangan. Bahan tambahan pangan yang digunakan oleh industri pangan dibedakan menjadi dua kelompok, yaitu bahan tambahan alami dan bahan tambahan sintetis [2].

Bleng atau borak merupakan salah satu bahan tambahan sintetis yang merupakan salah satu bahan yang dilarang digunakan dalam pangan. Boraks merupakan senyawa kimia yang berbentuk serbuk hablur Kristal transparan atau granul putih tak berwarna dan tak berbau serta agak manis [2]. Penambahan boraks pada makanan biasanya untuk meningkatkan kekenyalan, kerenyahan, memberikan rasa gurih dan kepadatan terutama pada jenis makanan yang mengandung pati [3].

Penggunaan bahan tambahan pangan boraks atau bleng dalam indistri pangan semakin luas dan meningkat. Banyak industri kecil, karena pendidikan dan pengetahuannya yang kurang, menggunakan bahan tambahan pangan boraks, salah satunya industri krupuk karak atau lempeng. Masyarakat 
menggunakan bahan tambahan tersebut untuk memperbaiki tekstur (kenyal) adonan karak (gendar), sehingga mudah pengirisannya, awet, setelah digoreng mengembang, empuk, teksturnya bagus dan renyah. Bahan tambahan pangan dalam pembuatan krupuk lempeng sebenarnya bisa menggunakan bahan yang lebih aman bagi kesehatan seperti hasil penelitian Hijrahati [4] menyatakan bahwa variasi penambahan tepung tapioca sebagai bahan pengganti bleng (boraks) menghasilkan kerupuk gendar dengan sifat fisik warna, aroma dan tekstur kerupuk gendar dengan tambahan tepung tapioca tidak berbeda dengan penambahan bleng, yaitu kerupuk gendar dengan penambahan tepung tapioca $25 \%$. Sedangkan hasil penelitian Setyowati [5] menyatakan karak goreng yang dihasilakan dari adonan yang ditambah bahan tambahan pangan CMC $0,75 \%: 1,00 \%$ dan STPP $\quad 0,7 \% \quad ; \quad 0,9 \%$ mempunyai volume pengembangan dan higrokopisitas relative sama dengan yang ditambah bleng.

Dalam peraturan Menteri Kesehatan No. 722/MenKes/Per/IX/88 boraks dinyatakan sebagai bahan berbahaya dan dilarang untuk digunakan dalam pembuatan makanan karena boraks merupakan racun bagi semua sel sehingga dapat berpengaruh buruk bagi kesehatan manusia.

Sektor usaha yang menjadi mitra dalam kegiatan PKM ini adalah Industri "Kerupuk Lempeng Mbak Gendhuk" yang terletak di Dusun Kepek I Timbulharjo Sewon Bantul Yogyakarta. Industri kerupuk lempeng mbak Gendhuk berdiri sejak tahun 1996 dengan modal awal Rp.1.000.000, yang didirikan oleh ibu Suratmi bersama suami. Saat ini Industri Krupuk lempeng mbak Gendhuk mempekerjakan 6 orang pegawai yang berasal dari Dusun Kepek I Timbulharjo Sewon Bantul. Omset industri Krupuk Lempeng Mbak Gendhuk saat ini rata-rata 7-10 juta perbulan. Industri ini sangat bergantung pada ke 5 tenaga kerja yang ada karena semua proses produksi di lakukan dengan menggunakan alat-alat tradisional, seperti mengiris legendar dengan pisau dapur. Jika ada pegawai yang tidak masuk maka proses produksi bisa menurun dan berimbas pada penurunan omset.

Mitra industri krupuk lempeng Mbak Gendhuk mempekerjakan tenaga kerja wanita. Saat memproses pembuatan krupuk lempeng terutama pada proses pengirisan kerupuk lempeng masih menggunakan pisau dapur, sehingga membutuhkan tenaga ekstra dan waktu yang panjang, selain itu pengemasan juga dilakukan seadanya yaitu hanya dimasukkan dalam kantong plastik dan karung.

\section{b. Permasalahan Mitra}

Beberapa permasalahan yang dapat diidentifikasi dari pengrajin kerupuk lempeng tersebut antara lain yaitu:

a. Keterbatasan modal yang dimiliki.

b. Keterbatasan produksi tidak sesuai permintaan (permintaan lebih besar dari produksi).

c. Penggunaan alat tradisional dan manual terutama alat pemotong krupuk, sehingga hasil produksi kurang maksimal.

d. Produksi masih memakai bahan tambahan boraks atau bleng karena kurangnya pengetahuan pemilik akan bahaya penggunaan boraks atau bleng.

e. Hasil produksi dikemas seadanya dan belum ada ijin PIRT, sehingga kurang menarik bagi pembeli.

f. Kurangnya pengetahuan pemilik dan tenaga kerja terhadap teknologi informasi sehingga sarana pemasaran terbatas.

Permasalahan diatas selanjutnya mengakibatkan usaha krupuk lempeng menjadi stagnan dan akan berimbas terhadap kurangnya penyerapan tenaga kerja disekitar wilayah usaha. Dalam proses pengolahan produksi terutama pemakaian bahan tambahan makanan sintetis atau boraks dapat membahayakan kesehatan konsumen dan pada saat mengiris krupuk masih tradisional sehingga produksi menjadi terbatas karena membutuhkan waktu yang lama dalam mengiris dan hasil produksi dikemas seadanya serta kurangnya pengetahuan pemilik terhadap teknologi informasi

Permasalahan yang dihadapi oleh mitra sangat beragam, sehingga dilakukan prioritas terhadap permasalahan yang akan diatasi melalui kegiatan PKM ini. Setelah dilakukan diskusi dengan mitra serta melihat kemampuan tim pelaksana PKM, maka dibuat skala prioritas sebagai berikut:

1. Penerapan teknologi tepat guna untuk meningkatkan nilai tambah hasil produksi.

2. Pelatihan pembuatan krupuk lempeng dengan bahan tambahan pangan STPP (Sodium tripolifosfat) sebagai pengganti boraks atau bleng.

3. Pengemasan produk dan IRT

4. Penerapan teknologi informasi terutama dalam memperluas jangkauan pemasaran.

\section{c. Target dan Luaran}

Sesuai dengan kegiatan yang telah direncanakan, maka jenis target dan luaran yang akan dihasilkan dari kegiatan ini adalah : 
a. Mitra dapat meningkatkan produksi krupuk lempeng baik yang sudah di goreng maupun yang belum di goreng.

b. Mitra dapat menghasilkan produksi krupuk yang aman dari bahan kimia (Boraks).

c. Mitra memiliki kemasan produk yang baik dan ijin PIRT.

d. Mitra dapat menggunakan teknologi informasi dalam memperluas jaringan pemasaran

\section{METODE KEGIATAN}

Tim pengabdian sebagai bagian dari masyarakat yang kebetulan berkecimpung dalam dunia pendidikan, merasa terpanggil untuk ikut membantu memberikan solusi terhadap permasalahan yang dihadapi. Melalui program kegiatan PKM ini dan berdasarkan analisis kebutuhan yang telah dilaksanakan, tim pengabdi menawarkan solusi terhadap permasalahan tersebut dengan sentuhan Ipteks, yaitu melalui kegiatan pokok

a. Penerapan teknologi tepat guna untuk meningkatkan nilai tambah hasil produksi, yaitu dengan menyediakan peralatan untuk memproduksi krupuk lempeng yaitu mesin pemotong krupuk.

b. Pelatihan pembuatan krupruk lempeng dengan bahan tambahan pangan yang aman bagi kesehatan sebagai pengganti boraks,

c. Pengemasan produk dan pengurusan ijin PIRT,

d. Pelatihan penggunaan teknologi informasi untuk memperluas jaringan pemasaran.

Skema pelaksanaan kegiatan program PKM Tim Pengabdian bersama dengan Mitra pada Gambar 1.

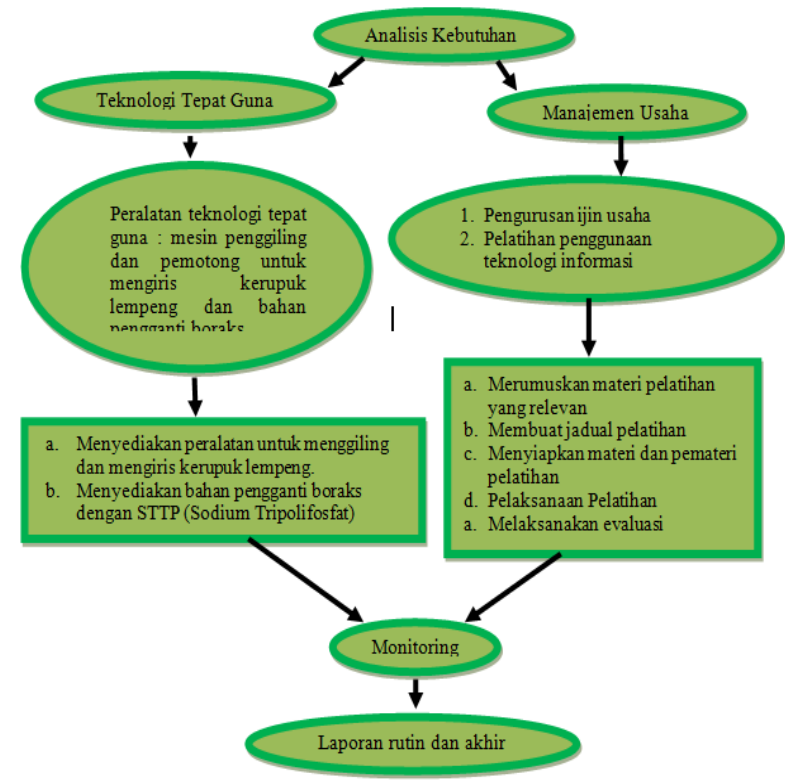

Gambar 1. Kegiatan Program PKM
Adapun kegiatan yang dilakukan untuk mencapai tujuan di atas adalah sebagai berikut :

a. Penerapan teknologi tepat guna untuk meningkatkan hasil produksi

Teknologi tepat guna yang dilakukan pada Mitra industri kerupuk lempeng dengan menerapkan mesin pengiris kerupuk lempeng. Penerapan teknologi ini sangat bermanfaat bagi mitra, karena selama ini pengirisan kerupuk lempeng dilakukan secara manual dengan diiris pakai pisau yang membutuhkan waktu yang cukup lama, dengan penerapan teknologi mesin pengiris bisa melakukan proses pengirisan dalam waktu cepat sehingga bisa meningkatkan jumlah produksi dan dapat memenuhi permintaan pasar.

b. Pelatihan peningkatkan nilai gizi kerupuk lempeng dengan menggunakan bahan tambahan STTP (Sodium Tripolifosfat) yang aman bagi kesehatan sebagai pengganti boraks.

Dalam proses produksi krupuk lempeng, sebagai bahan pengenyal kerupuk ditambahkan bahan tambahan pangan yang berupa STTP. Bahan tambahan tersebut digunakan untuk memperbaiki tekstur (kenyal) adonan kerupuk lempeng (gendar), sehingga mudah pengirisannya, awet, setelah digoreng mengembang, empuk, teksturnya bagus dan renyah.

STTP merupakan bahan tambahan pangan yang dapat meningkatkan pengikatan air oleh pati dan dapat meningkatkan daya serap air serta memperbaiki tekstur adonan yang kadar glutennya rendah, sedangkan fungsi umum bentuk fosfat dalam makanan antara lain meningkatkan daya ikat air dan hidrasi, pencegahan pengerasan dan sebagai pengawet makanan. Selain itu orthofosfat yang merupakan hasil hidrolisis polifosfat pada suhu tinggi dapat meningkatkan viskositas pasta dan ketahanan terhadap kerusakan akibat kejutan panas, pemotongan atau keasaman, demikian pula STPP dapat menyerap, mengikat dan menahan air, meningkatkan water holding capacity dan diharapkan penggunaan STTP dapat menghasilkan karak goreng dengan sifat fisik dan sensoris yang disukai. Selain itu STTP dapat menghasilkan kerupuk lempengyang sifatsifatnya tidak berbeda dengan kerupuk lempeng yang dibuat dengan bahan tambahan bleng atau boraks. 


\section{c. Pengemasan produk dan pengurusan ijin PIRT}

d. Pelatihan penggunaan teknologi informasi untuk memperluar jaringan pemasaran.

Facebook marketing adalah melakukan aktivitas marketing menggunakan semua fasilitas yang disediakan oleh facebook dengan tujuan meningkatkan penjualan (sales) dan menjalin komunikasi yang lebih langgeng dengan pelanggan (customer relationship).

\section{HASIL DAN PEMBAHASAN}

Pelaksanaan PKM ini dibagi menjadi 2 (dua) bagian yaitu yang pertama, penerapan teknologi tepat guna untuk produksi dan pemasaran, kemudian yang kedua, manajemen usaha. Adapun hasil dari kegiatan tersebut dibahas sebagai berikut :

a. Penerapan teknologi tepat guna, terutama pengadaan mesin penggiling dan mesin pengiris / pemotong kerupuk lempeng.

Teknologi tepat guna yang dipakai oleh mitra industri kerupuk lempeng berupa mesin penggiling adonan dan pengiris kerupuk lempeng, sangat membantu dan memberikan manfaat bagi mitra, karena selama ini penggilingan / pengadukan adonan masih secara manual yang memerlukan tenaga yang banyak dan membutuhkan waktu yang lama, begitu juga dengan pengirisan / pemotongan kerupuk lempeng diiris pakai pisau secara manual. Secara umum penggilingan adonan dan pengirisan kerupuk lempeng menjadi masalah yang cukup krusial bagi pelaku usaha kecil dan menengah terutama usaha makanan ringan, karena saat ini pelaku usaha mengalami kesulitan untuk mencari tenaga / pekerja untuk diberdayakan pada usaha makanan ringan, terutama pada industri kerupuk lempeng. Permasalahan berikutnya adalah proses produksi yang membutuhkan waktu yang cukup lama, dengan penerapan teknologi mesin pengaduk adonan dan pengiris kerupuk lempeng bisa melakukan proses pengadukan adonan dan pengirisan dalam waktu cepat dan sehingga bisa meningkatkan jumlah produksi dan dapat mengurangi biaya proses produk serta dapat memenuhi permintaan pasar. Mesin pengaduk adonan dan pengiris kerupuk lempeng pada Gambar 2 bekerja secara otomatis dengan menggunakan tenaga listrik.
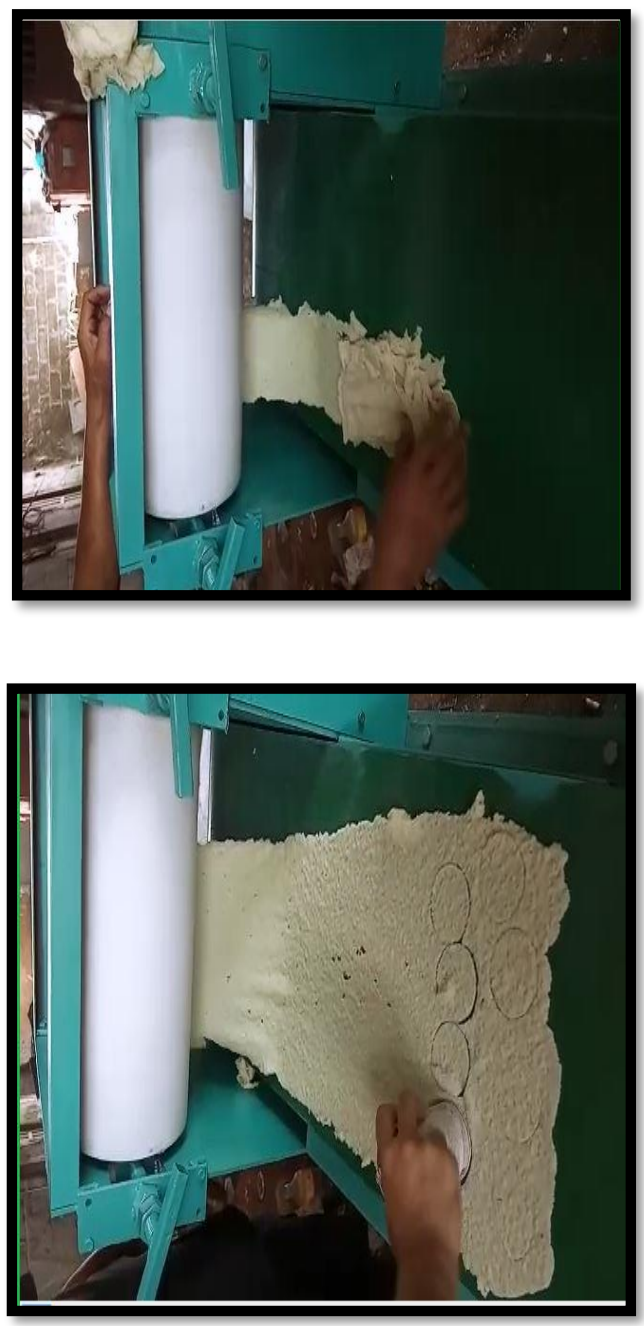

Gambar 2. Mesin Pengaduk Adonan dan Pengiris Kerupuk Lempeng

b. Pelatihan pembuatan krupruk lempeng dengan bahan tambahan pangan yang aman bagi kesehatan sebagai pengganti boraks.

Dalam proses produksi krupuk lempeng, sebagai bahan pengenyal kerupuk ditambahkan bahan tambahan pangan yang berupa STTP. Bahan tambahan tersebut digunakan untuk memperbaiki tekstur (kenyal) adonan kerupuk lempeng (gendar), sehingga mudah pengirisannya, awet, setelah digoreng mengembang, empuk, teksturnya bagus dan renyah.

STTP merupakan bahan tambahan pangan yang dapat meningkatkan pengikatan air oleh pati dan dapat meningkatkan daya serap air serta memperbaiki tekstur adonan yang kadar glutennya rendah, sedangkan fungsi umum bentuk fosfat dalam makanan antara lain meningkatkan daya ikat air dan hidrasi, pencegahan pengerasan dan sebagai pengawet makanan. Selain itu orthofosfat yang merupakan hasil hidrolisis polifosfat pada suhu tinggi dapat meningkatkan viskositas pasta dan ketahanan 
terhadap kerusakan akibat kejutan panas, pemotongan atau keasaman, demikian pula STPP dapat menyerap, mengikat dan menahan air, meningkatkan water holding capacity dan Diharapkan penggunaan STTP dapat menghasilkan karak goreng dengan sifat fisik dan sensoris yang disukai. Selain itu STTP dapat menghasilkan kerupuk lempengyang sifat-sifatnya tidak berbeda dengan kerupuk lempeng yang dibuat dengan bahan tambahan bleng atau boraks.

Secara umum proses pembuatan kerupuk lempeng tanpa bahan tambahan boraks melalui tahapan proses sebagai berikut :

\section{Persiapan}

1) Alat

Kompor, dandang sesuai banyaknya bahan, baskom besar, entong, alat penumbuk, alat pengiris lempeng, tambir atau Loyang dan alat pengering krupuk.

2) Bahan

Setengan ( $(1 / 2) \mathrm{kg}$ beras dicuci bersih, STTP 0,1 $\mathrm{mg}, 25$ gram bawang putih haluskan, 11/2 sdm garam, 1 sdt vetsin(sesuai selera), wajan ukuran besar, sotil dan serok, minyak goreng secukupnya, air $1000 \mathrm{ml}$.

\section{Cara membuat}

1) Campurkan STTP, bawang putih, vetsin, dan garam dengan $1000 \mathrm{ml}$ air aduk hingga merata

2) Rendamlah beras yang telah dicuci bersihdalam larutan STTP diamkan selama 2 jam, tiriskan beras, kemudian kukus selama 30 menit.

3) Didihkan $500 \mathrm{ml}$ air dan $1 \frac{1 / 2}{\mathrm{sdm}}$ garam, masukkan beras kukus, aduk-aduk hingga meresap. Kukus lagi selama 30 menit sampai matang, angkat. Lalu tumbuk halus beras.

4) Kemudian padatkan di loyang yang dialasi dengan plastik diamkan selama satu malam.

5) Iris dengan alat pengiris krupuk $10 \times 7 \mathrm{~cm}$, letakkan diatas tampah lalu dijemur dibawah terik matahari sampai kering jika cuaca mendung bisa dengan alat pengering krupuk.

6) Goreng di atas minyak yang telah dipanaskan di atas api yang sedang saja sampai matang.

Pelatihan produksi kerupuk lempeng dilakukan selama 5 (lima) hari yang dimulai pada tanggal 27 April - 1 Mei 2019, Selain kerupuk lempeng, tim PKM juga melakukan inovasi produk dengan membuat varian produk dengan berbagai rasa dan juga membuat produk lain selain kerupuk lempeng, misalnya rengginang dan kripik bakso proses pelatihan dapat dilihat pada Gambar 3.

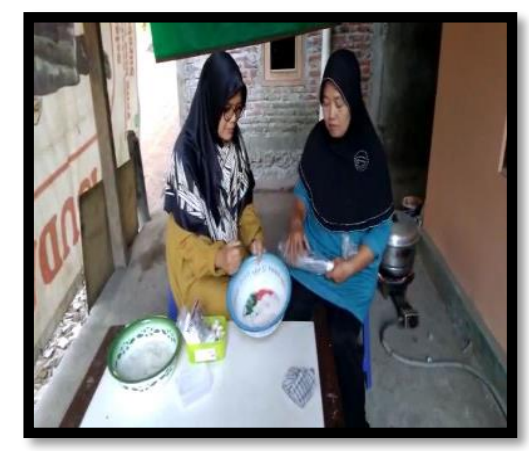

Gambar 3. Pelatihan Produksi Kerupuk Lempeng

c. Pengemasan produk baik untuk produk mentah maupun produk yang sudah digoreng serta aneka produk dengan berbagai rasa.

Pelatihan pengemasan produk dilakukan untuk meningkatkan nilai tambah dari produk kerupuk lempeng. Pengemasan yang dilakukan mitra selama ini masih konvensional sehingga kurang menarik minat dari pembeli. Selama ini produk hanya dijual kepada pengepul dengan harga yang murah, dan sisanya baru dijual dengan cara dititipkan ke warung - warung sekitar rumah mitra. Pelatihan yang dilakukan oleh Tim PKM sangat membantu mitra terutama dapat membuka wawasa mitra akan pentingnya pengemasan dilakukan secara baik dan menarik, sehingga akan dapat menarik minat pembeli, selain itu juga akan meningkatkan harga kerupuk lempeng. Produk yang dikemas selain kerupuk lempeng mentah juga mengemas produk yang sudah digoreng. Proses pelatihan pengemasan disajikan pada Gambar 4.

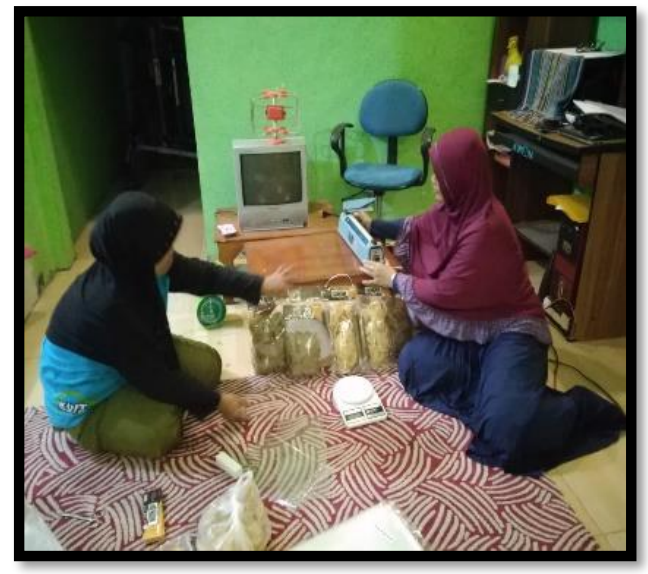

Gambar 4. Pelatihan Pengepakan Kerupuk Lempeng

\section{d. Pengurusan ijin P-IRT}

P-IRT merupakan salah satu program PKM yang menjadi prioritas dari Tim PKM, karena P-IRT adalah suatu legalitas bagi pelaku usaha makanan yang harus dimiliki. Selain legalitas P-IRT juga akan meningkatkan nilai tambah suatu produk kerupuk 
lempeng, karena dengan adanya P-IRT membuat konsumen merasa aman untuk mengkonsumsi kerupuk lempeng dan produk kerupuk lempeng mbak Gendhuk akan semakin dipercaya oleh konsumen. Proses pengurusan P-IRT sudah dilakukan oleh Tim PKM dengan mendaftarkan produk kerupuk lempeng ke Perijinan dan Dinas Kesehatan dan ikut serta dalam pelatihan.

\section{e. Pelatihan penggunaan teknologi informasi untuk memperluas jaringan pemasaran}

Facebook marketing adalah melakukan aktivitas marketing menggunakan semua fasilitas yang disediakan oleh facebook dengan tujuan meningkatkan penjualan (sales) dan menjalin komunikasi yang lebih langgeng dengan pelanggan (customer relationship). Konsep Facebook Marketing dapat digambarkan pada Gambar 5.

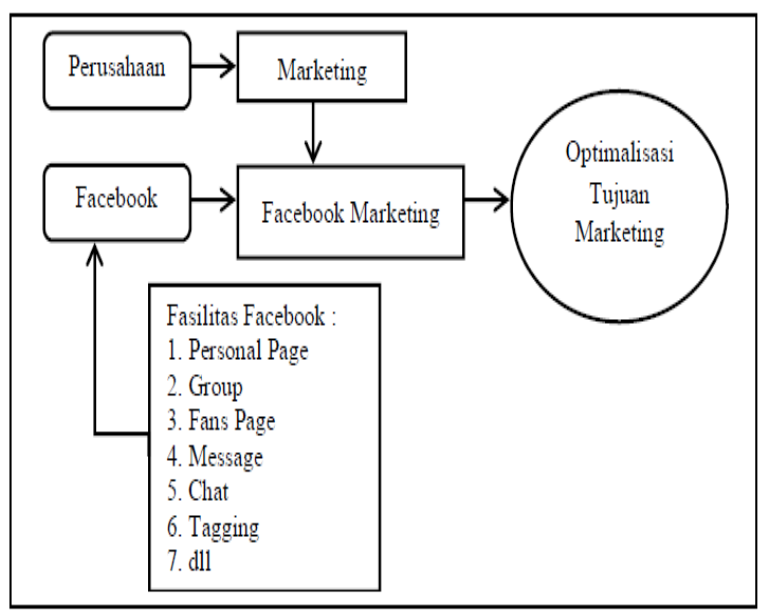

Gambar 5. Konsep Facebook Marketing

Tujuan marketing atau beberapa hal yang dapat dilakukan dalam Facebook marketing adalah sebagai berikut :

1) Communitization, Pembentukan komunitas yang terdiri dari orang-orang yang memiliki kepentingan dan ketertarikan yang sama yang terkait dengan produk anda.

2) Clarification, Membentuk persepsi tentang siapa dan apa produk kita di benak konsumen. Disamping itu dalam Clarification kita harus mampu menjawab dan memperjelas jika ada konsumen yang masih bingung atau memiliki persepsi yang berbeda tentang siapa dan apa produk kita.

3) Commercialization, Terjadinya penjualan kemudian membangun hubungan yang berkelanjutan.

4) Connection, Menjaga hubungan agar selalu dekat dengan pelanggan, melalui kedekatan ini dapat tercipta penjualan yang berkelanjutan.
5) Characterization, Meningkatkan brand awareness atau kesadaran terhadap merk, sehingga konsumen dapat dengan mudah mengingat, mengenali dan membedakan dengan jelas produk kita dengan produk yang lain,

6) Conversation, Membicarakan atau menyebarkan informasi kepada komunitas tentang apa yang kita lakukan, sehingga konsumen turut serta mempromosikan produk kita kepada konsumen lainnya,

7) Combination, Gabungan dua atau lebih tujuan dari Facebook marketing.

\section{KESIMPULAN DAN SARAN}

Program Kemitraan Masyarakat (PKM) dirasakan sangat membantu bagi Mitra, penggunaan teknologi tepat guna dalam bentuk mesin pengaduk adonan dan mesin pengiris kerupuk lempeng sangat membantu mitra dalam meningkatkan jumlah produksi dan dapat menekan biaya proses produksi. Produk yang dihasilkan juga aman untuk dikonsumsi, karena produk bebas dari boraks.

Selain produk aman untuk dikonsumsi, mitra juga dibekali dengan pelatihan pengemasan produk dan penambahan varian rasa serta jenis produk, juga mitra dibantu untuk mendapatkan ijin P-IRT sehingga bisa meningkatkan nilai tambah produk kerupuk lempeng.

Produk yang dihasilkan juga bisa dipasarkan secara online, karena mitra sudah dibekali pengetahuan untuk memanfaatkan media sosial sebagai sarana pemasaran, sehingga kerupuk lempeng mbak Gendhuk dapat dipromosikan secara global.

\section{UCAPAN TERIMAKASIH}

PKM ini terselenggaran atas dukungan dan kerja sama dari berbagai pihak, maka padakesempatan yang baik ini tim pengabdi mengucapkan banyak terima kasih kepada :

1. DRPM RistekDikti, atas dukungan dana Hibah

Program Kemitraan Masyarakat (PKM)

2. LLDIKTI Wilayah V

3. LPPM STIKes Surya Global Yogyakarta

4. Puslit dan PPM STMIK Akakom Yogyakarta

5. Semua pihak yang tidak bisa disebut satu persatu

\section{REFERENSI}

https://bantulkab.go.id/datapokok/0509_tenagakerja _pengangguran.html, diakses tanggal 9 Mei 2018 pukul 19.18 WIB) 
Cahayadi, Wisnu., 2009, Analisis dan Aspek Kesehatan Bahan Tambahan Pangan. Jakarta: Bumi Aksara

Saparinto, C., dan Hidayati., 2010, Bahan Tambahan Pangan. Yogyakarta : Kanisius

Hijrati, Nur., 2014, Variasi Penambahan Tepung Tapioka Sebagai Pengganti "Bleng" (Boraks) Dalam Pembuatan Kerupuk Gendar Ditinjau
Dari Sifat Fisik, Organelopatik dan Masa Simpan. Program Studi Ilmu Gizi Poltekes Yogyakarta.

Setyowati, A., 2010, Penambahan Natrium Tripolifosfat dan CMC (Carboxy Methyl Cellulose) Pada Pembuatan Karak. Jurnal AgriSains Vol.1. Maret 2010. 